\title{
Preparation of isocyanates by carbamates thermolysis on the example of butyl isocyanate
}

\author{
(C) Ratmir R. Dashkin, ${ }^{+}$Dmitry A. Gordeev, Khusrav Kh. Gafurov, and Sergey N. Mantrov* \\ Mendeleev University of Chemical Technology of Russia. Miusskaya St., 9. Moscow, 125047. \\ Russia.Phone: +7 (495) 944-32-73.E-mail: ratmir@engchem.ru
}

\begin{abstract}
*Supervising author; ${ }^{+}$Corresponding author
Keywords: kinetics, carbamates, thermolysis, isocyanate, $n$-butyl isocyanate.
\end{abstract}

Abstract
Butyl isocyanate is widely distributed as a precursor for the production of a number of biologically active substances: fungicides, preservatives, insecticides, personal care products, etc. Nowadays, there are a number of methods for the preparation of isocyanates, which can be divided into liquid phase and gas phase. One of the perspective methods for the production of isocyanates is the thermolysis of carbamate and/or the actions of various reaction activating agents, accompanied by the elimination of alcohol, but this process is reversible, which greatly complicates its use in industry. The paper presents the results of studies of noncatalytic thermal decomposition of $N$-alkylcarbamates with the formation of alkylisocyanates on the example of butylisocyanate in the gas phase, flow reactor in a wide temperature range $\left(200\right.$ to $\left.450{ }^{\circ} \mathrm{C}\right)$. In addition, a series of experiments was carried out using a catalyst, dibutyltin dilaurate, in order to reduce the thermolysis temperature and increase the yield of the final product. To implement the isocyanate production process, an experimental laboratory setup, consisting of a gas flow meter (argon) regulator, a packed column (for heating) and a sorption solution tank, was developed and tested. The thermolysis of $N$ - $n$-butylcarbamate was carried out in two variations: the preparation of an individual $n$-butylisocyanate and the passage of reaction products through a sorption solution linking the $n$-butyl isocyanate to $N$-n-butyl- $N$ '-(1-phenylethyl)urea, which allows to estimate the yield of the target $n$-butylisocyanate without additional losses. The analysis of the obtained substances was carried out by high performance liquid chromatography with a UV detector (target product) and a mass detector (analysis of by-products). According to the results of research, a modification of the laboratory facility was proposed, as well as $n$-butylisocyanate was obtained with a yield of $49 \%$ on the basis of a new technique.

\section{References}

[1] M.R. Piazza. Composite building module U.S. Patent No. 3,984,957 Int. Cl. E04C2/288. 1976.

[2] T.A. Unger. Pesticide synthesis handbook. William Andrew. 1996. 570p.

[3] D.A. Gordeev, M.U. Komaritskikh, and S.N. Mantrov. Kinetics and mechanism of 2-hydroxyethyl carbamates transesterification. Butlerov Communications. 2017. Vol.49. No.3. P.1-11. DOI: 10.37952/ROI-jbc-01/1749-3-1

[4] A. Gitchaiwat, et al. Assessment and characterization of antifungal and antialgal performances for biocide-enhanced linear low-density polyethylene. J. Appl. Polym. Sci. 2013. Vol.128. No.1. P.371-379.

[5] R.H. Elslahi et al. Comparative study of the fungicide Benomyl toxicity on some plant growth promoting bacteria and some fungi in pure cultures Interdisciplinary Toxicology. 2014. Vol.7. No.1. P.12-16.

[6] D.G. Gotovsky, O.P. Sedukova. Disinsection, dezinvasia and deratization at the objects of veterinary supervision. 2016. 48p. (russian)

[7] K.H. Slotta, R. Tschesche. Über Isocyanate, II.: Umsetzungen des Methylisocyanates unter dem Einfluß von Triäthylphosphin. Berichte der deutschen chemischen Gesellschaft (A and B Series). 1927. Vol.60. No.2. P.295-301.

[8] G.M. Edelman. Dissociation of $\gamma$-globulin. Journal of the American Chemical Society. 1959. Vol.81. No.12. P.3155-3156.

[9] T.D.J. D'Silva et al. Studies of methyl isocyanate chemistry in the Bhopal incident. Journal Organic Chemistry. 1986. Vol.51. No.20. P.3781-3788.

[10] E. Dyer, G.C. Wright. Thermal degradation of alkyl $N$-phenylcarbamates. Journal of the American Chemical Society. 1959. Vol.81. No.9. P.2138-2143.

[11] N. Bortnick et al. $t$-Carbinamines, $\mathrm{RR}^{\prime} \mathrm{R}^{\prime} \mathrm{CNH}_{2}$. III. The Preparation of Isocyanates, Isothiocyanates and Related Compounds. Journal of the American Chemical Society. 1956. Vol.78. No.17. P.43584361. 
[12] Schweitzer, Carl E. Chemical process and products. U.S. Patent No. 2,409,712. 1946.

[13] T.E. Waldman, W.D. McGhee. Isocyanates from primary amines and carbon dioxide: 'dehydration' of carbamate anions. Journal of the Chemical Society, Chemical Communications. 1994. No.8. P.957-958.

[14] Newman M. Bortuick, Oreland, Pa., assignor to Rohm \& Haas Company, Philadelphia, Pa., a corporation of Delaware No Drawing. Preparation or Organic Isocyanates U.S. Patent No. 2,713,591. 1952.

[15] D.N. Mai, J.P. Wolfe. Asymmetric palladium-catalyzed carboamination reactions for the synthesis of enantiomerically enriched 2-(arylmethyl)-and 2-(alkenylmethyl) pyrrolidines. Journal of the American Chemical Society. 2010. Vol.132. No.35. P.12157-12159.

[16] M. Shinohata, N. Miyake. Isocyanate production process. U.S. Patent No. 2011,092,731. 2011.

[17] K. Liu, M.E. Meyerhoff. Preparation and characterization of an improved $\mathrm{Cu} 2+-$ cyclen polyurethane material that catalyzes generation of nitric oxide from S-nitrosothiols. Journal Materials Chemistry. 2012. Vol. 22. No.36. P. 18784-18787.

[18] Barclay, Jr Robert, and Raymond P. Kurkjy. Organic isocyanate preparation. U.S. Patent No. 3,076,007. 1963. 